\title{
端部回転を有する免震用積層ゴムの水平剛性と取付け部材の設計用応力 に関する研究

\author{
A STUDY ON LATERAL STIFFNESS AND DESIGN STRESS OF INSTALL MEMBER \\ ON LAMINATED RUBBER BEARINGS SUBJECTED TO END ROTATION
}

\author{
小林正人*，下田＼cjkstart卓**，西村拓也*** \\ Masahito KOBAYASHI, Suguru SHIMODA and Takuya NISHIMURA
}

\begin{abstract}
The purpose of this study is to gain an understanding of the lateral stiffness of laminated rubber bearings subjected to end rotation, and design stress of member to install in end of laminated rubber bearings. To understand the mechanical properties of laminated rubber bearings subjected to end rotation, the mechanical properties of laminated rubber bearings concatenated the rotational spring are evaluated. In addition, the degree of fluctuation in lateral stiffness and bending moment are evaluated by using the analytical model assuming a base isolated building with inclination of pile top.
\end{abstract}

Keywords : Base-isolation, Laminated rubber bearing, End rotation, Stiffness degradation,

Bending moment distribution, Coupled model

免震，積層ゴム，端部回転，剛性低下，曲げモーメント分布，連成モデル

\section{1. はじめに}

免震建物の設計において，免震デバイスとして一般的な積層ゴム を用いる場合，通常積層ゴムの上下には剛強な二重基礎が設けられ る。この場合，積層ゴム取付け部の固定度は十分に大きいため，積 層ゴム端部の回転は拘束され安定した水平挙動を示す。一方, 免震 建物の建設コストの削減や免震層の有効利用の観点, または耐震改 修の一手法として，柱頭・杭頭に直接免震装置を設置する柱頭・杭 頭免震構造の建設事例が報告されており，2011 年東北地方太平洋沖 地震において杭頭免震構法を適用した実建物で免震効果が確認され ている 1)。

柱頭・杭頭免震では, 柱間や柱頭・杭頭に直接免震デバイスを設 置するため，二重基礎を省略または簡略化することがある。これら の構法では積層ゴム取付け部の固定度が低下寸るため, 地震時には 積層ゴム端部に回転が生じる。回転により生じる積層ゴムの軸心の 傾斜により，鉛直荷重の分力が付加せん断力として働き積層ゴムの 水平変位が増加する。従来の積層ゴムの剛性評価式では積層ゴム端 部回転の影響を考慮していないため, 設計時においては端部回転を 考慮して剛性評価を行う必要がある。

積層ゴムの水平剛性と座屈荷重に関する古典的力学理論として Haringx 理論がよく知られており, 積層ゴムの一般的な剛性評価式 は端部の回転を拘束した条件下で求められている 2)。積層ゴムの端 部回転を考慮した水平剛性評価式として, 浅野・嶺脇ら 3は積層ゴ
ムの存在応力に応じて曲げモーメント - 回転角関係における非線形 特性を逐次計算することで任意の忘力状態における積層ゴムの特性 を評価している。飯塚 ${ }^{4}$ は Haringx 理論に基づき端部の回転を考慮 した剛性マトリクスの定式化を行っている。また，飯塚・高岡ら5) は積層ゴムを高さ方向に分割し，各分割要素を回転ばね，せん断ば 放，剛体要素で構成したモデルに材料非線形特性を導入し，大変形 域までの挙動を追跡できるモデルへの拡張を行っている。三山 ${ }^{6}$ は 飯塚の提案する剛性マトリクスに基づき，積層ゴムの面圧依存性や 変位依存性の影響を考慮し，剛棒に曲げばねとせん断ばねを用いた モデルにより物理的な意味を明解にした剛性マトリクスを示してい る。これらの手法の多くは各種特性の設定がやや難解で高度な専門 知識が必要となるが，積層ゴムの非線形特性や各種依存性，ハード ニングなどを精密に評価することが可能である。

積層ゴムに取付く部材の設計用応力については，積層ゴムの高さ 方向における曲げモーメント分布は端部回転が発生しない場合, 反 曲点位置が積層ゴム中心に位置するため，上下端部が負担する曲げ モーメントは均等である。しかし, 端部回転が発生すると反曲点位 置が回転の生じる端部側に移動し，曲げモーメント分布に変化が生 じため, 積層ゴム端部モーメントの増加量を適切に評価する必要が ある7)。

本論では端部回転を有する積層ゴムの剛性評価手法として三山の 評価式 6)を採用し，端部回転を有する積層ゴムの特性を評価する。

\footnotetext{
* 明治大学理工学部建築学科 准教授・博士 (工学)

*** 明治大学大学院理工学研究科建築学専攻 博士前期課程

*** 清水建設株技術研究所 主任研究員・修士 (工学)
}

Assoc. Prof., Dept. of Architecture, School of Science and Technology, Meiji Univ., Dr. Eng. Dept. of Architecture, Graduate School of Science and Technology, Meiji Univ. Senior Research Engineer, Institute of Technology, Shimizu Corporation, M. Eng. 
さらに, 積層ゴムに取付く部材の回転剛性を回転ばねに集約し, 積 層ゴムの水平剛性低下の割合と取付け部に作用寸る曲げモーメント の増減率について評価する。また, 杭頭免震建物を想定した積層ゴ ム一杭一基礎梁連成解析モデルにより実架構を想定した回転剛性評 価および周辺部材の応力状態を評価する。

\section{2. 端部回転を有する積層ゴムの構成則}

\section{1 三山の剛性評価手法}

三山は飯塚の提案する Haringx 理論に基づく剛性評価式の物理 的な意味をより明確化し, 積層ゴムのせん断剛性および回転剛性に 関する水平变位依存性を導入した剛性方程式を提案している。この 手法は $4 \times 4$ のマトリクス演算であり, 既往の評価式の中でも比較 的簡易に表現されている。また，各剛性項を分割して扱えるため， 積層ゴムごとに異なる非線形特性を導入しやすいという利点があり， 評価式としての汎用性も高い。端部回転を有する積層ゴムの評価モ デルを図 1 に示す。このモデルに基づく, 積層ゴムの荷重変形関係 は(1)式で表される。

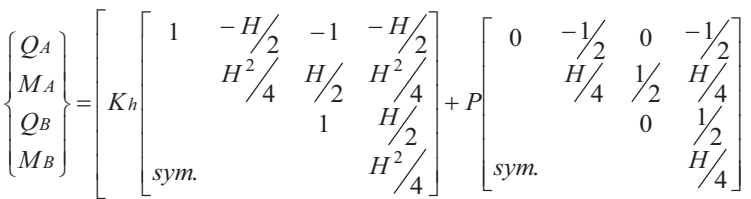

$$
\begin{aligned}
& \left.+K r\left[\begin{array}{cccc}
0 & 0 & 0 & 0 \\
& 1 & 0 & -1 \\
& & 0 & 0 \\
\text { sym. } & & & 1
\end{array}\right]\right]\left\{\begin{array}{l}
x_{A} \\
\theta_{A} \\
x_{B} \\
\theta_{B}
\end{array}\right\}
\end{aligned}
$$

ここで, $Q_{A}: A$ 点のせん断力, $Q_{B}: B$ 点のせん断力, $M_{A}: A$ 点の曲げモーメント, $M_{B}: B$ 点の曲げモーメント, $x_{A}: A$ 点の変 位, $x B: B$ 点の変位, $\theta_{A}: A$ 点の回転角, $\theta_{B}: B$ 点の回転角, $P$ : 鉛直軸力, $H$ : 積層ゴム高さ(ゴム厚+鋼板厚)である。

積層ゴムの水平剛性 $K h$ および回転剛性 $K r$ は積層ゴムに作用する 軸力に伴う非線形性を有する。積層ゴムの水平剛性 $K h$, 回転剛性 $K r$
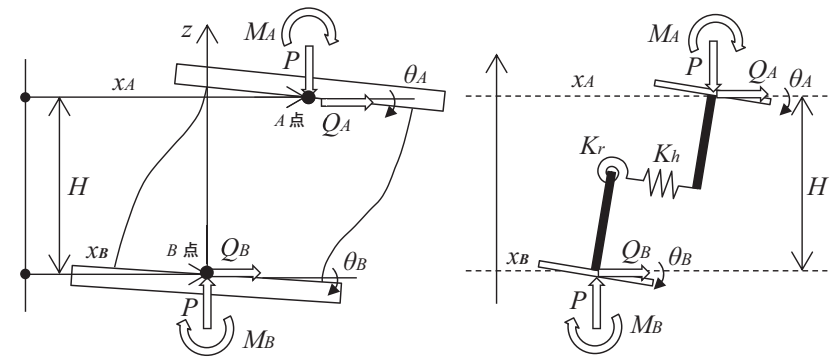

図 1 積層ゴムの評価モデル

は座屈荷重 $P_{c r}$ の影響を考慮して(2) (4)式によって表される。

$$
\begin{aligned}
& K_{h}=\frac{G \cdot A}{n t_{r}}\left(1-\left(\frac{P}{P_{c r}}\right)^{2}\right) \cdot \phi_{h} \\
& K_{r}=\frac{E_{r b} \cdot I}{n t_{r}}\left(1-\left(\frac{P}{P_{c r}}\right)^{2}\right) \cdot \phi_{r c} \cdot \phi_{\sigma}
\end{aligned}
$$

$$
P_{c r}=\frac{\pi}{n t_{r}} \sqrt{G \cdot A \cdot E_{r b} \cdot I}
$$

ここで， $G$ : ゴムのせん断弾性率， $A$ : ゴム部のせん断断面積, $n$ ：ゴム層数， $t r$ ：ゴム 1 層厚さ， $E_{r b}$ ：体積弹性率で補正された ゴムの曲げ弾性係数 8)，I：ゴム部の断面 2 次モーメントである。

(2)式では積層ゴムの水平剛性に水平変位依存性 $\phi h$ を考慮してい る。積層ゴムはせん断ひずみ $\gamma$ の増加に伴い水平剛性が低下し，一 定のひずみレベルを超えるとハードニングにより水平剛性が増加す る特徵があるが，積層ゴムごとにその特性は異なるため，実験によ り評価することが一般的である。三山は，水平剛性の水平変位依存 性を圧縮せん断実験に基づき評価している。せん断ひずみ $\gamma=100 \%$ 時の積層ゴムの割線剛性を基準とし，試験体の各ひずみレベルでの 割線剛性の低下率を近似式により示したものとなる。積層ゴムの水 平変位依存性 $\phi h$ は(5)式で表される。

$$
\phi_{h}=\left(\frac{x}{n t_{r}}\right)^{u}
$$

ここで, $u$ は図 2 に示す水平変位依存性の曲線形状を決定する係 数であり，実験結果より定められる。 $u=0$ のとき，常に $\phi h=1$ とな り，積層ゴムの水平剛性を線形として扱うことができる。文献 6)で は実験結果より求めた水平変位依存性と一致するように $u=-0.16$ としている。

また， $K r$ は(3)式より図 3 に示す水平変位依存性 $\phi_{r c}$ 考慮してい る。図 4 に示寸ように, 変形 $x$ 時において積層ゴムの回転変形に関 する有効断面積を上下面が重なる領域 $S$ とすると, $\phi_{r c}$ は領域 $S$ の 重心を通る直線 $y$ 軸まわりの断面 2 次モーメントと積層ゴム全断 面の断面 2 次モーメントの比となる。よって，回転剛性に関する水 平変位依存性 $\phi r c$ は積層ゴム円形断面の直径 $D$ を用いて(6)式, (7) 式で表される。

$$
\phi_{r c}=\frac{4}{\pi}\left(\frac{1}{2} \theta_{d}+2 \theta_{d} \cos ^{2} \theta_{d}-\frac{13}{6} \sin ^{3} \theta_{d} \cos \theta_{d}-\frac{5}{2} \sin \theta_{d} \cos ^{3} \theta_{d}\right)
$$

$\theta_{d}=\cos ^{-1}(x / D)$

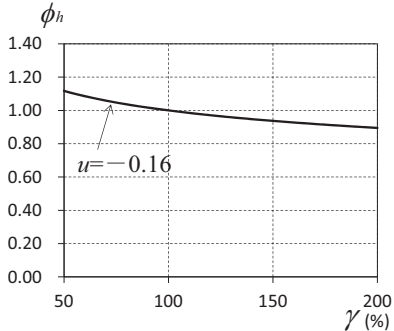

図 2 水平剛性の変位依存性

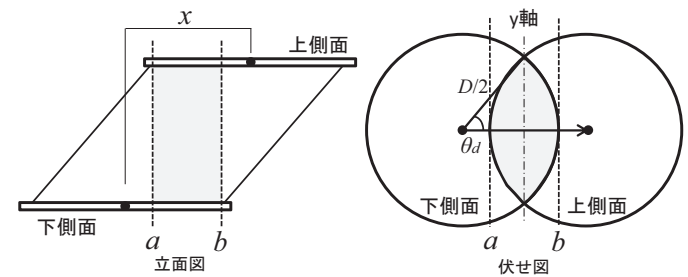

図 4 曲げに関する有効断面

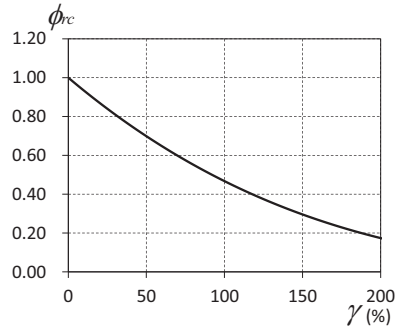

図 3 回転剛性の変位依存性 
図 3 に示寸ように, $\phi_{r}$ は積層ゴムの水平変位 $x$ の増加とともに 低下し, 積層ゴム上下面の重なりがなくなるとき $(x / D=0)$ に $\phi_{r c}=0$ となる。

文献 9)では, 積層ゴムのゴム部において平面保持を仮定して求め た縁応力度 $\sigma$ が引張降伏応力度 $\sigma_{y}$ に達すると回転剛性 $K_{r}$ が非線形 となる材料非線形特性 $\phi \sigma$ を考慮している。積層ゴムの降伏回転角 $\theta_{y}$ は(8)式で表し，材料非線形特性 $\phi_{\sigma}$ は(9)，(10)式で表される。

$$
\begin{array}{ll}
\theta_{y}=\frac{Z\left(P / A+\sigma_{y}\right)}{\left(K_{h} H^{2} / 4+P H / 4+K_{r}\right)} & \left(|\theta| \leqq \theta_{y}, \theta=\theta_{A}-\theta_{B}\right) \\
\phi_{\sigma}=1 & \left(\left|\theta_{y}\right|>\theta_{y}\right) \\
\phi_{\sigma}=\frac{1}{1+\frac{\alpha}{\beta}\left(\left|\frac{\theta}{\theta_{y}}\right|-1\right)^{\frac{1+\alpha}{\alpha}}} &
\end{array}
$$

ここで, $Z$ : ゴム部の断面係数, $\sigma_{y}$ : ゴム部の引張降伏応力度, $\theta_{y}$ : ゴム部の降伏回転角である。（10)式における $\alpha$ および $\beta$ は, 積層ゴムの曲げモーメントー回転角の履歴形状に係わる係数で, 積 層ゴムの圧縮せん断試験より定まる值となる。本論では文献 9) と同 様に $\alpha=10, \beta=40$ と寸る。図 5 に材料非線形特性 $\phi \sigma$ と上下面の 相対回転角 $\theta$ を降伏回転角 $\theta y$ により無次元化した $\theta / \theta y$ との関係を 示す。 $\theta / \theta_{y}$ が 1 以上となると， $\phi \sigma$ は $\theta$ の上昇とともに漸減する。

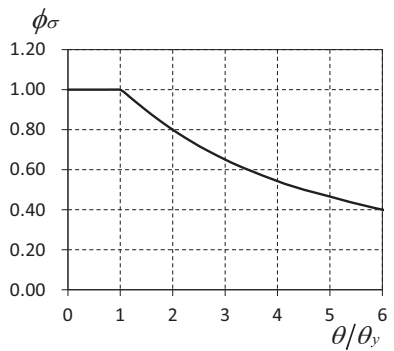

図 5 回転剛性の材料非線形

\section{2 積層ゴム端部の曲げモーメント}

水平変位 $\delta$ を有し, 軸力 $P$ を受ける積層ゴムに作用する曲げモ ーメント $M$ は(11)式により表される。

$$
M=Q \cdot H+P \cdot \delta
$$

積層ゴム端部に回転が生じない場合, 積層ゴムの反曲点が積層ゴ ム高さ方向の中心となるため, 上下端に生じる曲げモーメント $M_{0}$ は 上下等分割となり(12)式で表される。

$$
M_{0}=\frac{1}{2} Q \cdot H+\frac{1}{2} P \cdot \delta
$$

しかし, 図 6 に示すように積層ゴムの端部に回転が生じると固定 度の低下に伴い, 積層ゴムの反曲点が回転側へ移動し積層ゴム取付 け部が負担する曲げモーメントの割合が変化する。回転を有する端 部の曲げモーメント $M B$ は(12)式の值よりも減少し, 他方の端部の 負担する曲げモーメント $M_{A}$ は(12)式の值よりも増加することにな る。そこで，本節では積層ゴムせん断ひずみの増加に伴う端部モー メントの変動を検討する。回転発生側の下端部 $B$ 点の負担曲げモー
メント $M_{B}$ は(12)式の $M_{0}$ よりも減少するため, 負担曲げモーメント が増加する回転の発生しない上端部 $A$ 点に着目する。積層ゴム上端 部が負担する曲げモーメント $M_{A}$ を(12)式で示す回転が生じない場 合の曲げモーメント $M_{0}$ で基準化し，曲げモーメント増加率 $\alpha M$ を (13)式で定義する。

$$
\alpha_{M}=\frac{M_{A}}{M_{0}}
$$

ここで， $\alpha M=1.0$ の場合は，端部回転がなく積層ゴム取付け部の 負担する曲げモーメントは上下等分割となり， $\alpha M=2.0$ に近づくに つれて下端がピン支持状態に近づくことになる。

ここで，(1)式における積層ゴムの上端モーメント $M_{A}$ は $x_{B}=0$, $\theta_{A}=0$ と仮定し，(1)式を展開することで(14)式により表される。

$$
M_{A}=-x_{A} \cdot K h \cdot \frac{H}{2}-x_{A} \cdot \frac{P}{2}+\frac{\theta_{B} \cdot H^{2}}{4} K h+\frac{\theta_{B} \cdot H}{4} P-\theta_{B} \cdot K r
$$

（14)式を(13)式に代入すると，増加率 $\alpha M$ は(15)式で表される。

$$
\alpha_{M}=\frac{M_{A}}{M_{0}}=1+\left\{\frac{\theta_{B}}{2 x_{A}} \cdot\left(\frac{4 K r}{K h \cdot H+P}-H\right)\right\}
$$

図 7 にせん断ひずみ $200 \%$ 時における積層ゴム上下端の曲げモー メント増加率 $\alpha M$ と端部回転角の関係を示す。(a)は面圧 $10 \mathrm{~N} / \mathrm{mm}^{2}$, (b)は面圧 $20 \mathrm{~N} / \mathrm{mm}^{2}$ の結果である。各面圧における積層ゴムの降伏 回転角 $\theta y$ の值を 2 点鎖線で示す。また, 眓中の点線は(10)式で示す ゴムの材料非線形を無視した場合の結果である。ゴムの材料非線形 を無視した場合は, 端部回転の増加に対して曲げモーメント増加率 $\alpha M$ は比例的に増加の傾向を示す。しかし，ゴムの材料非線形を考 慮すると, 降伏後はモーメント増加率 $\alpha M$ の増加は緩慢になり終局 的には $\alpha M=1.00$ に向かう。また，面圧の増加に伴い同じ回転角に 対する増加率 $\alpha M$ の值は減少する傾向にある。これは, 変位 $x_{A}$ およ び端部回転角 $\theta B$ が等しい場合, (15)式においての変数項が軸力 $P$ の みであることからも理解できる。

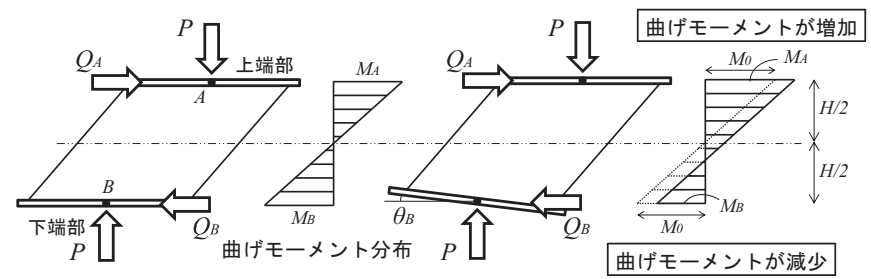

図 6 端部回転に伴う曲げモーメント分布の変化

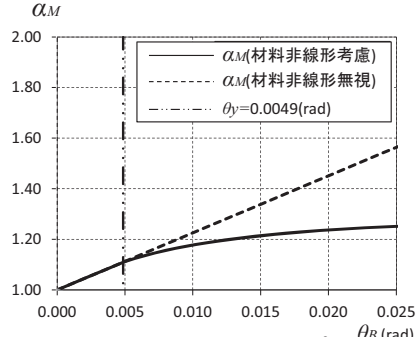

(a) 面圧 $10 \mathrm{~N} / \mathrm{mm}^{2} \quad \theta_{B}(\mathrm{rad})$

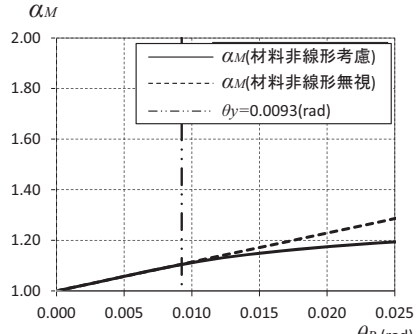

(b) 面圧 $20 \mathrm{~N} / \mathrm{mm}^{2} \quad \theta_{B}$ (rad)

図 $7 \gamma=200 \%$ 時における $\alpha_{\mathrm{M}}{ }^{-} \theta_{\mathrm{B}}$ 関係

\section{3. 連結部材の回転剛性を考慮した連成解析}

\section{1 解析モデル}

積層ゴム端部の回転角は，積層ゴムが取付く部材の剛性に左右さ 
れる。そこで, 本論では図 1 に示寸積層ゴム力学モデルの下端に線 形回転ばね $K B$ を連結し, 柱や杭, 基礎梁など積層ゴムの端部に取 付く部材（連結部材と称する）の回転剛性を考慮した連成解析を行 う。解析モデルを図 8 に示す。積層ゴムの上端部には十分に剛強な 部材が取り付くと仮定し, 境界条件として回転を拘束した。一方, 積層ゴムの下端部は回転を考慮し, 水平自由度を拘束している。

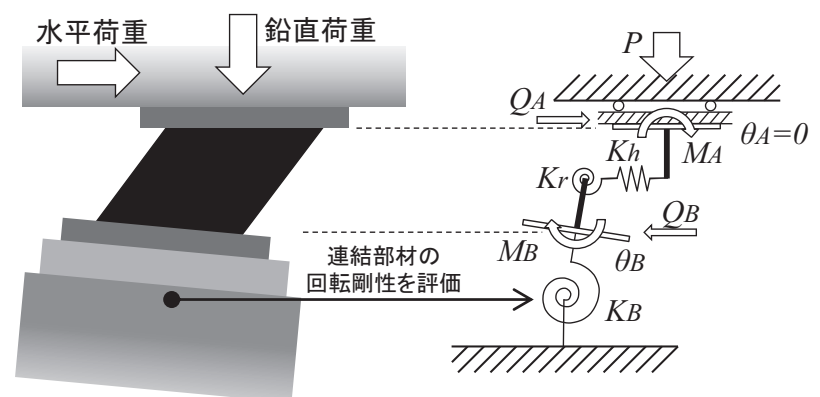

図 8 連結部材連成モデル

\section{2 解析パラメータ}

使用する積層ゴムとしては, せん断弾性率 $0.392 \mathrm{~N} / \mathrm{mm}^{2}$, 2 次形 状係数が 5.0 の免震用積層ゴムとして一般的なものを用いるとし， 文献 11)に掲載されている代表的な積層ゴムの諸元を用いた。参考 值として表 1 に外径 $600 \mathrm{~mm}$ の積層ゴムの諸元を示す。

図 8 に示寸解析モデルでは, 連結部材の回転剛性を集約した回転 ばね $K B$ を導入している。そこで, 連結部材の回転剛性の大きさを示 寸指標として, 積層ゴムの回転剛性 $K r c$ を連結部材の回転剛性 $K B$ で無次元化した回転剛性比 $K r c / K B$ を用いる。ここで, $K r c$ は軸力の 影響を無視した積層ゴムの回転剛性で下式により表される。

$$
K_{r c}=\frac{E_{r b} \cdot I}{n t_{r}}
$$

柱頭・杭頭免震と異なり通常の二重基礎を有する基礎免震構造で は, 積層ゴム端部の回転剛性 $K B$ が十分に大きいため, 回転剛性比 $K r c / K B$ は 0.00 に近い值となり端部の回転角も微小な值となる。よ って, 回転剛性比 $K r c / K B$ が小さい值となるにつれて, 端部の固定 度が十分に大きい構造とみなせる。逆に, 連結部材の回転剛性 $K_{B}$ が 小さくなるにつれて回転剛性比 $K r c / K B$ の值は増加し, 端部回転角も 大きくなる。すなわち, 回転剛性比 $K r c / K B$ は端部回転のしやすさ を示す指標となる。

検討する解析パラメータは, せん断ひずみを $50 \%, 100 \%, 150 \%$, $200 \%$ に固定し, せん断ひずみレベル毎に連結部材の回転剛性 $K B$ を 変動させる。また, 面圧は長期, 短期荷重を想定し $10 \mathrm{~N} / \mathrm{mm}^{2}$ およ び 20N/mm²の 2 パターンとする。

表 1 積層ゴム諸元（外径 $600 \mathrm{~mm}$ )

\begin{tabular}{|c|c|c|c|c|c|}
\hline 外径 $D$ & 600 & $\mathrm{~mm}$ & 内部鋼板厚 $t s$ & 5.0 & $\mathrm{~mm}$ \\
\hline 内径 $d$ & 13.5 & $\mathrm{~mm}$ & せん断弾性率 $G$ & 0.392 & $\mathrm{~N} / \mathrm{mm}^{2}$ \\
\hline 1 次形状係数 $S_{1}$ & 36.6 & - & ヤング率 $E_{0}$ & 0.22 & $\mathrm{~N} / \mathrm{mm}^{2}$ \\
\hline 2次形状係数 $S_{2}$ & 5.0 & - & 体積弾性率 $E_{\infty}$ & 1960 & $\mathrm{~N} / \mathrm{mm}^{2}$ \\
\hline ゴム層数 $n$ & 30 & - & 補正係数 $\kappa$ & 0.88 & - \\
\hline ゴム厚 $t r$ & 4.0 & $\mathrm{~mm}$ & 引張降伏応力度 $\sigma_{y}$ & 1.00 & $\mathrm{~N} / \mathrm{mm}^{2}$ \\
\hline
\end{tabular}

\section{3 水平剛性低下率}

文献 11)における外径 $600 \mathrm{~mm}, 700 \mathrm{~mm}, 800 \mathrm{~mm}, 900 \mathrm{~mm}$,
$1000 \mathrm{~mm}$ の積層ゴムに対し解析を行ったところ, 積層ゴムの外径差 が水平剛性低下率や回転角, 曲げモーメント増加率に与える影響は 小さく解析結果の差も数\%であった。差異の原因としては, ゴムシー 卜厚と内部鋼板厚の比率が径ごとに若干異なることがあげられる。 よって, 2 次形状係数が等しければ積層ゴムの特性変化に大きな差 は生じないとし，上記の外径における解析結果の平均値により各種 特性変化を評価する。

図 9 に水平剛性低下率 $K e q / K h 0.00$ と回転剛性比 $K r c / K_{B}$ の関係を 示す。水平剛性低下率 $K e q / K h 0.00$ は，せん断ひずみレベル毎の荷重 変形関係から求めた割線剛性を $K e q$ とすると, 回転の生じない場合

$\left(K_{r c} / K_{B}=0.00\right)$ のせん断ひずみレベル毎の割線剛性 $K h 0.00$ で $K e q$ を除した $K e q / K h 0.00$ と定義する。凡例に示すのは, せん断ひず みレベルで(a)が面圧 $10 \mathrm{~N} / \mathrm{mm}^{2}$ の結果，(b)が面圧 $20 \mathrm{~N} / \mathrm{mm}^{2}$ の結果 である。両面圧の結果を比較すると積層ゴムの水平剛性低下率は面 圧に大きく影響を受けることが分かる。ここで，連結部材の回転剛 性が積層ゴムの回転剛性と等しい回転剛性比 $K r c / K B=1.00$ に着目 する。本解析の最大振幅であるせん断ひずみ $\gamma=200 \%$ 時において, 水平剛性低下率は面圧 $10 \mathrm{~N} / \mathrm{mm}^{2}$ では $5 \%$ 程度の低下にとどまるが, 面圧 $20 \mathrm{~N} / \mathrm{mm}^{2}$ では $20 \%$ 近くもの剛性低下が生じる。例えば，本論 では $10 \%$ 以下の水平剛性低下に抑えるとすると面圧 $10 \mathrm{~N} / \mathrm{mm}^{2}$ では 回転剛性比が 2.50 以下，面圧 $20 \mathrm{~N} / \mathrm{mm}^{2}$ では回転剛性比が 0.50 以 下となるように連結部材の回転剛性を確保する必要がある。

\section{4 端部回転角}

図 10 に端部回転角 $\theta_{B}$ と回転剛性比 $K_{r} / K_{B}$ の関係を示す。図 10 において，(a)と(b)を比較すると面圧が 2 倍になることで端部回転

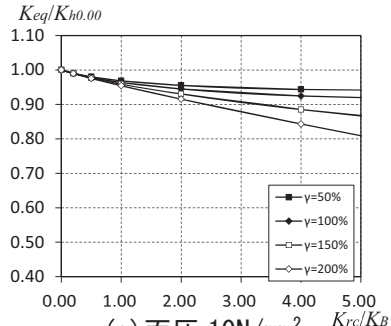

(a) 面圧 $10 \mathrm{~N} / \mathrm{mm}^{2} \quad K r c / K$

図 9 水平剛性低下率一回転剛性比関係

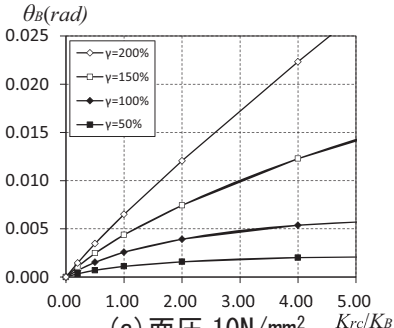

(a) 面圧 $10 \mathrm{~N} / \mathrm{mm}^{2} \quad K r \mathrm{r} / K$

図 10 端部回転角一回転剛性比関係

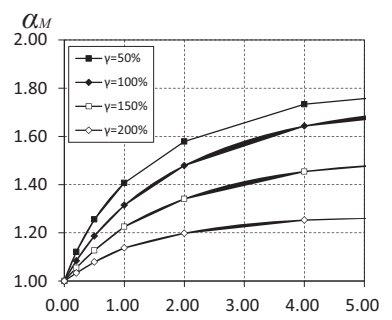

(a) 面圧 $10 \mathrm{~N} / \mathrm{mm}^{2} \quad \mathrm{Krc} / \mathrm{K}_{B}$

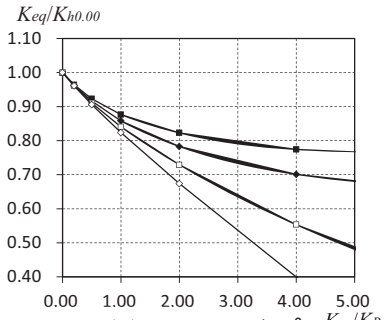

(b) 面圧 $20 \mathrm{~N} / \mathrm{mm}^{2} \quad K_{r c} / K_{B}$

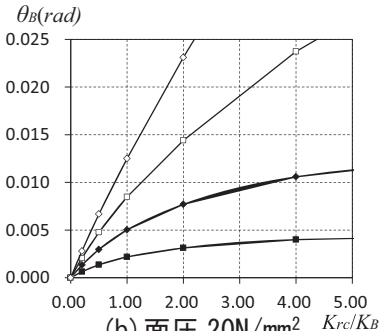

(b) 面压 $20 \mathrm{~N} / \mathrm{mm}^{2} \quad K r c / K_{B}$

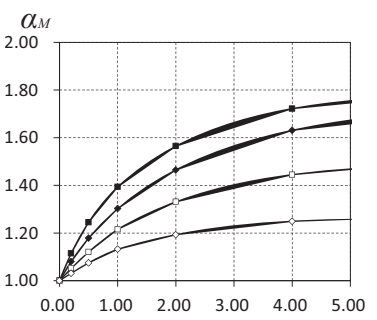

(b) 面圧 $20 \mathrm{~N} / \mathrm{mm}^{2} \quad \mathrm{Krc} / \mathrm{K}$
図 11 モーメント増加率一回転剛性比関係 
角の值もおよそ 2 倍となっている。また，杭頭免震建物の設計にお いて端部回転角の制限を1/100(0.01 rad)以下とする事例 12)がみられ る。本論においても端部回転角の制限を 0.01 rad 以下とすると, せ ん断ひずみ $\gamma=200 \%$ 時において, 面圧 $10 \mathrm{~N} / \mathrm{mm}^{2}$ では回転剛性比が 1.60 以下, 面圧 $20 \mathrm{~N} / \mathrm{mm}^{2}$ では回転剛性比が 0.75 以下となるように 連結部材の回転剛性を確保する必要がある。ここで，端部回転角 $0.01 \mathrm{rad}$ 以下となる上記の回転剛性比における水平剛性低下率を図 9 より求めると, 面圧 $10 \mathrm{~N} / \mathrm{mm}^{2}$ の回転剛性比 1.60 では $7 \%$ 程度の 水平剛性低下であり, 面圧 $20 \mathrm{~N} / \mathrm{mm}^{2}$ の回転剛性比 0.75 では $14 \%$ 程 度の水平剛性低下となる。

また, 基䃈免震構造の積層ゴムの施工精度管理基準 13)では, 積層 ゴムの傾きの精度管理は概ね 1/400(0.0025rad)以下と定められてい る。施工精度基準と同等の端部回転角となる回転剛性比は $\gamma=$ $200 \%$ 時の面圧 $10 \mathrm{~N} / \mathrm{mm}^{2}$ では 0.30 以下, 面圧 $20 \mathrm{~N} / \mathrm{mm}^{2}$ では 0.17 以下の回転剛性比を確保する必要があり, 端部回転角 $0.01 \mathrm{rad}$ 以下 となる回転剛性と比べ 4 ～倍の回転剛性が連結部材に必要となる。

\section{5 曲げモーメント増加率}

図 11 に積層ゴム上端の曲げモーメント増加率 $\alpha M$ と回転剛性比 $K_{r c} / K_{B}$ の関係を示す。(a)と(b)を比較すると面圧が変化しても増加 率に大きな変化は確認されない。(15)式において, 積層ゴムの水平 変位 $x_{A}$ を定めると増加率 $\alpha M$ は積層ゴムの端部回転角 $\theta_{B}$ および軸 力 $P$ により決定する。図 11 において軸力 $P$ が増加しても増加率 $\alpha M$ に大きな差が見られないことは, 軸力 $P$ の増加に対して積層ゴ 么端部回転角 $\theta B$ が相対的に増加していることによるものと考えら れる。

積層ゴムのせん断ひずみが増加すると, 水平変位依存性 $\phi_{r c}$ によ り積層ゴムの回転剛性は低下寸るため, 曲げモーメント増加率 $\alpha_{M}$ は小さくなる。また, せん断ひずみが増加すると積層ゴムの材料非 線形 $\phi \sigma$ によ積層ゴム上端部は降伏する状態になる。よって, せん 断ひずみが増加するほど降伏曲げモーメントは小さくなるため曲げ モーメント増加率 $\alpha M$ の值も減少する。本解析において積層ゴムの 降伏時の $\alpha_{M}$ は, 面圧 $10 \mathrm{~N} / \mathrm{mm}^{2}$ で $\alpha_{M}=1.27$, 面圧 $20 \mathrm{~N} / \mathrm{mm}^{2}$ で $\alpha M$ $=1.25$ となる。

端部回転角 $0.01 \mathrm{rad}$ 以下を満たす回転剛性比は, 3.4 節で述べた とおり, 面圧 $10 \mathrm{~N} / \mathrm{mm}^{2}$ では 1.60 以下, 面圧 $20 \mathrm{~N} / \mathrm{mm}^{2}$ では 0.75 以 下である必要がある。そこで, 最大振幅であるせん断ひずみ $\gamma$ $=200 \%$ 時の曲げモーメント増加率を求めると, 面圧 $10 \mathrm{~N} / \mathrm{mm}^{2}$, 回 転剛性比 1.60 では $\alpha_{M}=1.29$, 面圧 $20 \mathrm{~N} / \mathrm{mm}^{2}$, 回転剛性比 0.75 で は $\alpha M=1.10$ である。面圧が大きいほど連結部材に必要とされる回
転剛性は大きくなるため, 回転剛性比は小さな值となりモーメント 増加率の值も小さくなる。しかし, 面圧の増加により(11)式に示す 積層ゴムに生じる曲げモーメントは増加しているため, 端部曲げモ 一メントの值の算定には注意が必要である。これらの結果から, 端 部回転角 0.01rad の制限を設けた場合, 積層ゴムに取付く部材の設 計には, 端部回転が生じない場合に対して $10 〜 20 \%$ の曲げモーメン トの割り増しが必要となる。

\section{4. 積層ゴムー杭一基礎梁連成解析}

\section{1 解析モデル}

杭頭免震構法を利用した建物を想定し，連結部材の回転剛性の評 価および周辺部材への影響を把握する。図 12 に解析モデルを示す。 積層ゴム 1 基を中心とした周辺架構を解析対象範囲としており, 積 層ゴムの上端部には上部構造の剛強な基礎梁が取付くと仮定し, 積 層ゴム，基礎梁，杭，地盤をモデル化する。使用する積層ゴムは表 1 に示す外径 $600 \mathrm{~mm}$ のものを使用する。

杭は場所打ちコンクリート杭とし, 杭径を $900 \mathrm{~mm}$, 杭長を $15 \mathrm{~m}$ とした。杭先端部はピン支持とし, 杭は長さ $1000 \mathrm{~mm}$ ごとに分割し た直交分割要素モデルとして扱う。また，杭断面の非線形特性は文 献 14)を参考に定める。下式によりひび割れモーメント M c および 降伏モーメント $M y$ を算定する。

$$
\begin{aligned}
& M_{c r}=0.56 \sqrt{F c} \cdot Z+N D / 6 \\
& M_{y}=0.9 a t \cdot \sigma_{y} \cdot d
\end{aligned}
$$

ここで， $F_{c}$ ：コンクリート設計基準強度 $\left(\mathrm{N} / \mathrm{mm}^{2}\right), \quad Z$ : 断面係 数, $N$ : 軸力, $D$ : 部材せい, $a t$ : 引張鉄筋の断面積, $\sigma y$ : 主筋 の降伏引張応力度, $d$ : 有効せいとする。本論では, コンクリート 設計基準強度を $24 \mathrm{~N} / \mathrm{mm}^{2}$ とし, 引張鉄筋比を $1.2 \%$, 主筋の降伏引 張応力度を $390 \mathrm{~N} / \mathrm{mm}^{2}$ とした。曲げモーメント $M$ 一曲率 $\phi$ 関係を 図 13(a)に示す。なお，杭の 3 次剛性は初期剛性の 1/1000 とした。

基礎梁は $\mathrm{RC}$ 造とし梁幅を $1000 \mathrm{~mm}$, スパン長を $10 \mathrm{~m}$, 梁の反曲 点位置はスパン中央と仮定し $5 \mathrm{~m}$ の位置にローラー支持を設けるも のとする。基礎梁は, 杭頭部との接合をピン接合として回転に無抵 抗とした場合, 梁せいを $300 \mathrm{~mm}$ とした回転拘束効果をある程度有 する場合を検討する。なお, 杭と同様にコンクリート強度を $24 \mathrm{~N} / \mathrm{mm}^{2}$ とし, 主筋の許容引張応力度を $390 \mathrm{~N} / \mathrm{mm}^{2}$ とした。基礎 梁においては引張鉄筋比を $0.6 \%$ と, 基礎梁の 3 次剛性は初期剛 性の $1 / 1000,1000 \mathrm{~mm}$ 間隔で分割した直交分割要素モデルとして

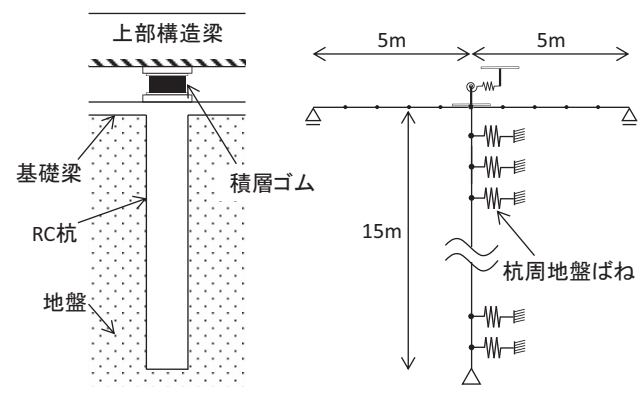

図 12 積層ゴム一杭一基礎梁連成解析モデル

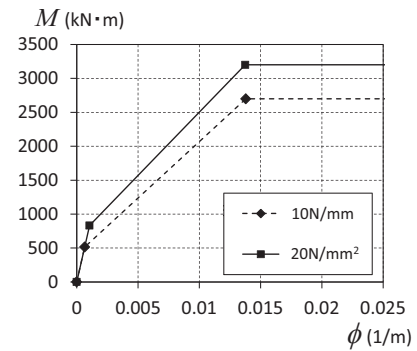

(a) 杭断面の M- $\phi$ 関係

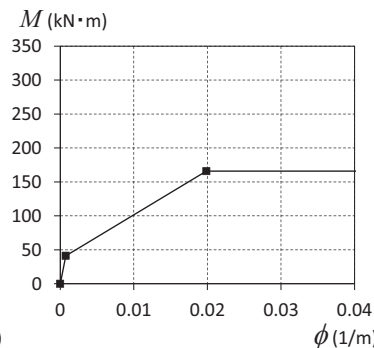

(b) 梁断面の $M-\phi$ 関係

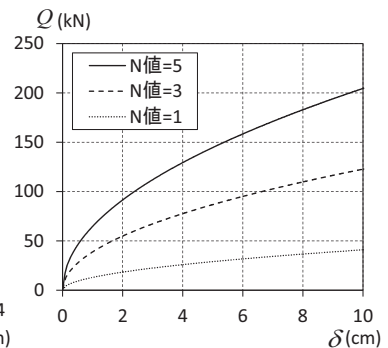

(c) 地盤の Q- $\delta$ 関係
図 13 非線形特性 
扱う。図 13(b)に基礎梁断面の曲げモーメント $M$ 一曲率 $\phi$ 関係を示 す。

地盤は，粘性土の一様地盤とし $N$ 值=1，3，5 の 3 パターンにつ いて検討し, $1000 \mathrm{~mm}$ 間隔で分割した杭の各節点に杭周地盤ばねを 設け評価する。また, 杭周地盤ば礼には地盤の非線形特性を考慮す るものとし，文献 15)を参考に下式により評価する。

$$
\begin{aligned}
& K h_{0}=\alpha \cdot \xi \cdot E_{0} \cdot \bar{B}^{-3 / 4} \\
& E_{0}=700 \cdot N \\
& K h=3.16 \cdot K h_{0} \cdot B \quad(0.0 \leqq \bar{y} \leqq 0.1) \\
& K h=K h_{0} \cdot y^{-1 / 2} \cdot B \quad(0.1<\bar{y})
\end{aligned}
$$

ここで，Kho：水平地盤反力係数 $\left(\mathrm{kN} / \mathrm{m}^{3}\right), \quad \alpha$ : 評価法による係 数(本論においては $\alpha=60), \quad \xi$ : 群杭の影響を考慮した係数, $E_{0}$ ： 変形係数 $\left(\mathrm{kN} / \mathrm{m}^{2}\right), \bar{B}$ : 杭径を $\mathrm{cm}$ 単位で無次元化した数值, $N$ : 地盤の $N$ 值, $B$ : 杭径 $(\mathrm{m}), \bar{y}$ : 水平変位を $\mathrm{cm}$ 単位で無次元化し た数值である。せん断力 $Q$-せん断変位 $\delta$ 関係を図 13(c)に示す。

\section{2 回転剛性比の評価}

積層ゴムのせん断ひずみは $\gamma=50 \sim 200 \%$ 範囲で検討し, 面圧を $10 \mathrm{~N} / \mathrm{mm}^{2}$ および $20 \mathrm{~N} / \mathrm{mm}^{2}$ とした。また, 基礎梁と杭頭の接合がピ ンの場合をPin と表記し，基礎梁の梁せいが $300 \mathrm{~mm}$ の場合を 300 と表記する。地盤の $N$ 值は $1 ， 3 ， 5$ と変動させ $\mathrm{N} 1 ， \mathrm{~N} 3 ， \mathrm{~N} 5$ と表 記する。表 2 に示寸ように, 解析ケースを面圧一基礎梁形式 $-N$ 值 の順に表記する。図 12 に示す積層ゴム一杭一基礎梁連成解析モデ ルの積層ゴム上端部に, 軸力および水平変位を与え, 杭頭部の回転 角および各部曲げモーメント等を評価する。なお，本解析において は，地震時の地盤応答変位の影響は考慮していない。この点につい ては今後の課題とする。解析結果を以下に示す。

図 14 は, 図 9 に連成解析の結果を重衫合わせたものであり, 水 平剛性低下率 $K e q / K h 0.00$ と回転剛性比 $K r c / K B$ の関係を示してい る。凡例には, 解析ケースを示す。 $N$ 值が大きくなると回転剛性比 は小さくなるが回転剛性比 0.50 前後で変化の割合は小さくなる。こ の傾向は，面圧が増加しても大きく変わらない。また，両面圧とも Pin-N1，300-N1 以外のケースでは一体解析モデルの回転剛性比は 概小 0.75 以下に収まっており, 水平剛性低下率も $10 \%$ 以下に収ま る結果となっている。梁せい $300 \mathrm{~mm}$ の基礎梁による回転拘束効果 はみとめられるものの, 地盤による回転拘束効果のほうが影響は大

\begin{tabular}{|c|c|c|c|c|}
\hline No. & せん断歪みү & 面圧 $\sigma$ & 基礎梁形式 & $\mathrm{N}$ 值 \\
\hline$\sigma 10-$ Pin $^{-N} 1$ & \multirow{12}{*}{$50 \%, 100 \%, 150 \%, 200 \%$} & \multirow{6}{*}{$10 \mathrm{~N} / \mathrm{mm}^{2}$} & \multirow{3}{*}{ Pin } & 1 \\
\hline$\sigma 10-$ Pin $^{-N} 3$ & & & & 3 \\
\hline$\sigma 10-$ Pin-N5 & & & & 5 \\
\hline$\sigma 10-300-\mathrm{N} 1$ & & & \multirow{3}{*}{$300 \mathrm{~mm}$} & 1 \\
\hline$\sigma 10-300-N 3$ & & & & 3 \\
\hline$\sigma 10-300-N 5$ & & & & 5 \\
\hline$\sigma 20-\operatorname{Pin}-\mathrm{N} 1$ & & \multirow{6}{*}{$20 \mathrm{~N} / \mathrm{mm}^{2}$} & \multirow{3}{*}{ Pin } & 1 \\
\hline$\sigma 20-\operatorname{Pin}-\mathrm{N} 3$ & & & & 3 \\
\hline$\sigma 20-\operatorname{Pin}-\mathrm{N} 5$ & & & & 5 \\
\hline$\sigma 20-300-\mathrm{N} 1$ & & & \multirow{3}{*}{$300 \mathrm{~mm}$} & 1 \\
\hline$\sigma 20-300-\mathrm{N} 3$ & & & & 3 \\
\hline$\sigma 20-300-N 5$ & & & & 5 \\
\hline
\end{tabular}
きい。また，せん断ひずみ $\gamma=150 \%$ 前後で $\sigma$ 10-Pin-N1 のケースの 回転剛性比の值に差がみられるのは杭および地盤の非線形特性の影

表 2 連成解析パラメータ

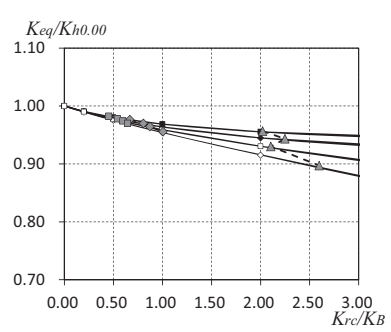

(a) 面圧 $10 \mathrm{~N} / \mathrm{mm}^{2}(\mathrm{Pin})$

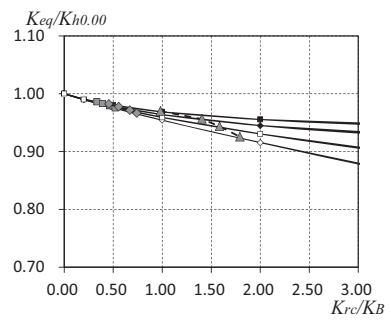

(c) 面压 $10 \mathrm{~N} / \mathrm{mm}^{2}(300)$

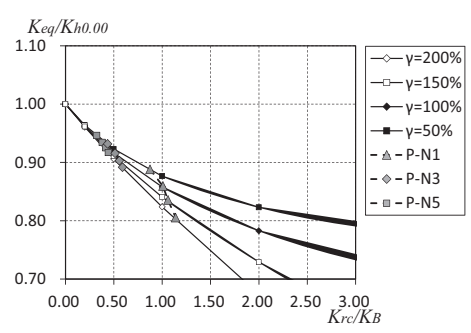

(b) 面圧 $20 \mathrm{~N} / \mathrm{mm}^{2}$ (Pin)

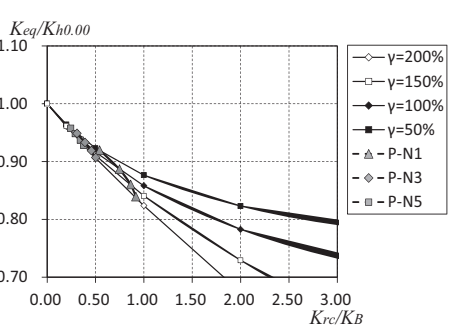

(d) 面圧 $20 \mathrm{~N} / \mathrm{mm}^{2}(300)$
図 14 水平剛性低下率一回転剛性比関係

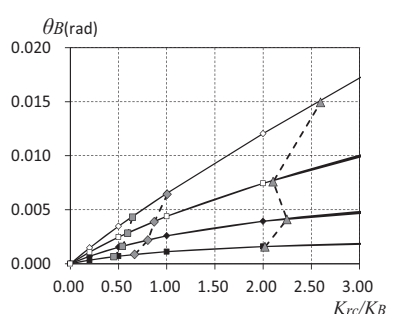

(a) 面圧 $10 \mathrm{~N} / \mathrm{mm}^{2}$ (Pin)

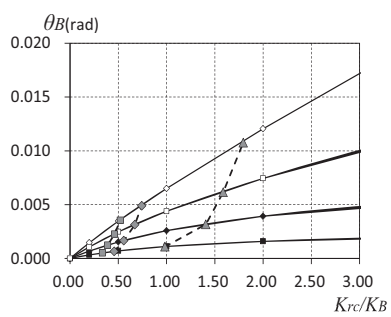

(c) 面圧 $10 \mathrm{~N} / \mathrm{mm}^{2}(300)$

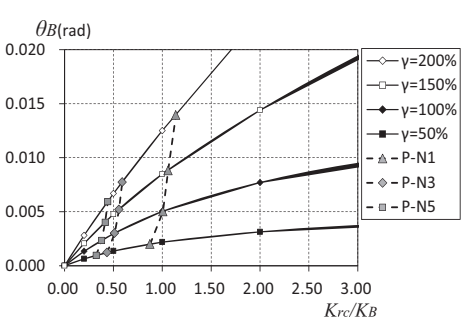

(b) 面圧 $20 \mathrm{~N} / \mathrm{mm}^{2}$ (Pin)

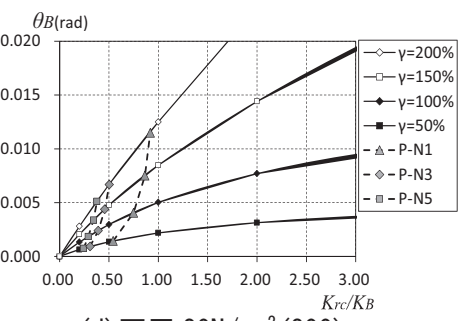

(d) 面圧 $20 \mathrm{~N} / \mathrm{mm}^{2}(300)$
図 15 端部回転角一回転剛性比関係

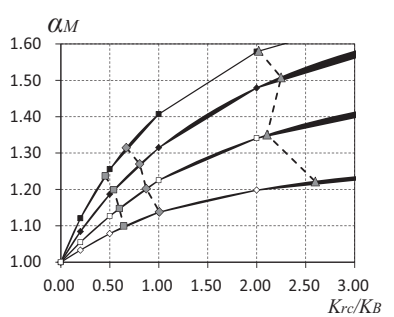

(a) 面圧 $10 \mathrm{~N} / \mathrm{mm}^{2}(\mathrm{Pin})$

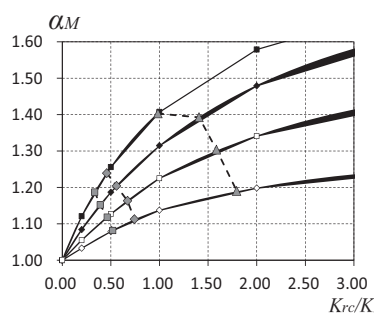

(c) 面圧 $10 \mathrm{~N} / \mathrm{mm}^{2}(300)$

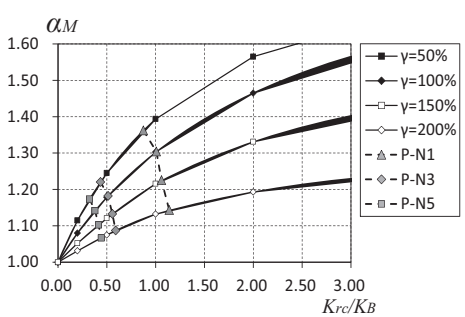

(b) 面圧 $20 \mathrm{~N} / \mathrm{mm}^{2}$ (Pin)

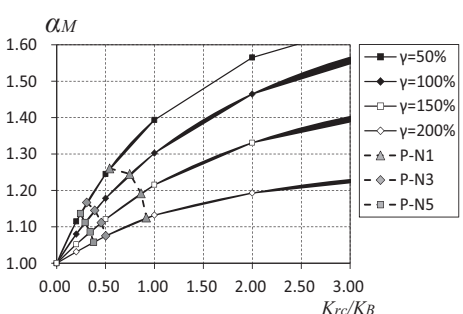

(d) 面圧 $20 \mathrm{~N} / \mathrm{mm}^{2}(300)$
図 16 曲げモーメント増加率一回転剛性比関係 
響によるものと考えられる。

図 15 には, 同様に端部回転角 $\theta_{B}$ の比較を示す。(a), (b)のPin では $N$ 值=1の場合に $0.01 \mathrm{rad}$ をきく上回る端部回転角が生じる。 (c)，（d）に示すように，基礎梁による回転拘束効果が見込める 300 では，端部回転を0.01 rad 程度に抑えることができる。このことか ら, 基礎梁の梁せいを調節することで端部回転角を 0.01 $\mathrm{rad}$ 程度以 下に抑えられる回転剛性の確保が可能となることがわかる。また, $N$ 值 $=1$ 以外のパターンは $0.01 \mathrm{rad}$ 以下の回転角に収まる結果となっ ている。

図 16 には，曲げモーメント増加率 $\alpha M$ の比較を示す。 3.5 節にお ける連結部材連成モデルでは面圧の変化による曲げモーメント増加 率の大きな変化はみられないが, 実架構を想定した連成モデルでは 杭や基䃈梁, 地盤の各種非線形特性により, 積層ゴム一杭一基礎梁 連成解析モデルの回転剛性が変化するため面圧の変化に伴い増加率 $\alpha M$ も変化する。せん断ひずみ $\gamma=200 \%$ 時に着目すると， $\sigma$ 10-Pin-N1 では，20\%を超えるモーメント増加が生じており， $\sigma$ 10-Pin-N3， o 10-Pin-N5 においても 10\%前後の曲げモーメント増 加が確認できる。また, 面圧 $20 \mathrm{~N} / \mathrm{mm}^{2}$ においても， $\alpha M$ は 1.07〜 1.14 の範囲にある結果となった。よって, この結果からも積層ゴム に取付く部材の設計においては, 端部回転が生じない場合に対して 10〜20\%の曲げモーメント増加を考慮すべきであるといえる。

以上の結果から, 本論における解析モデルの回転剛性比の範囲は $0.25 \sim 2.60$ であり, 端部回転角には基礎梁の剛性および地盤の $N$ 值 が大きく影響していることが把握される。

\section{3 周辺部材に生じる曲げモーメント}

図 17 に示すように積層ゴム一杭一基礎梁連成解析モデルの各部 材に生じる曲げモーメントを定義し, 各部材に生じる曲げモーメン トの大小関係をせん断ひずみレベル毎に評価する。基礎梁形式ごと に比較し, 基礎梁と杭頭の接合がピン接合であるPin の場合におけ る曲げモーメント - せん断ひずみ関係を図 18 に, 基礎梁の梁せい が $300 \mathrm{~mm}$ で回転拘束効果を有する 300 の場合を図 19 に示す。

図 18 において，Pinの場合は基礎梁が負担するモーメントが 0 であるため, 積層ゴム下端のモーメント $M_{B}$ と杭頭モーメント $M P H$ は等しい值をとる。また, 連成解析モデルの回転剛性比が大 きくなる程, 杭中間部での最大モーメント $M_{P \max }$ の值は大きくなり 回転剛性比が小さくなるほど, 杭頭が負担する曲げモーメントは大 きくなる。杭のひび割れモーメント $M_{c r} P$ は面圧 $10 \mathrm{~N} / \mathrm{mm}^{2}$ におい ては $514 \mathrm{kN} \cdot \mathrm{m}$ であり, 面圧 $20 \mathrm{~N} / \mathrm{mm}^{2}$ においては $832 \mathrm{kN} \cdot \mathrm{m}$ で ある。せん断ひずみ $\gamma=200 \%$ 時に注目すると, Pin の場合において

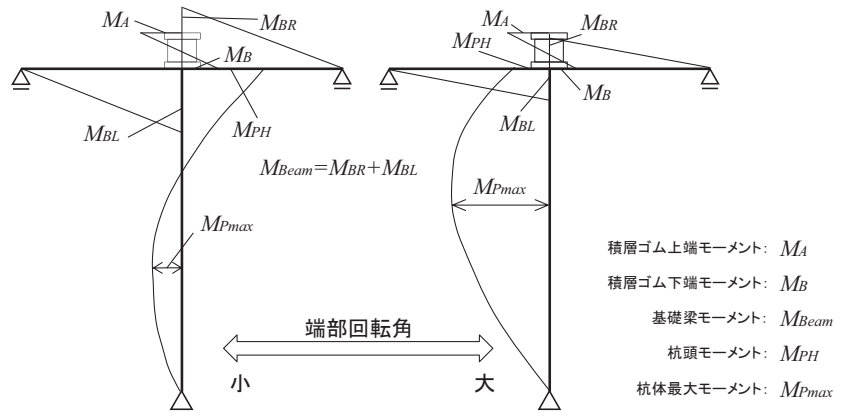

図 17 周辺部材に生じる曲げモーメント

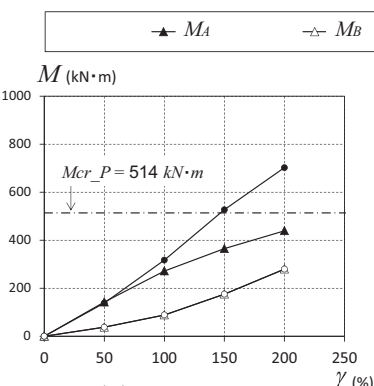

(a) $\sigma 10-\operatorname{Pin}-\mathrm{N} 1$

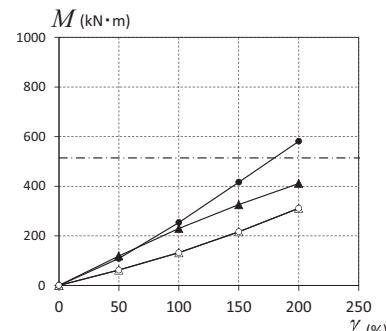

(c) $\sigma 10-\mathrm{Pin}-\mathrm{N3}$

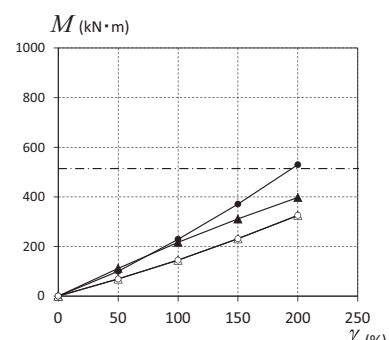

(e) $\sigma$ 10-Pin-N5

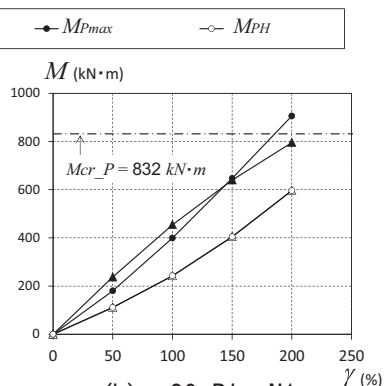

(b) $\sigma$ 20-Pin-N1

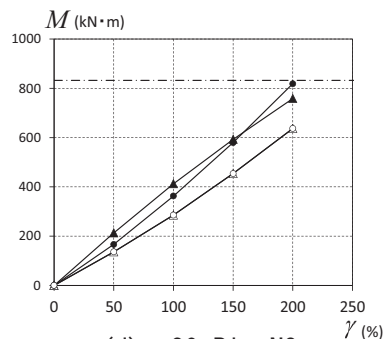

(d) $\sigma$ 20-Pin-N3

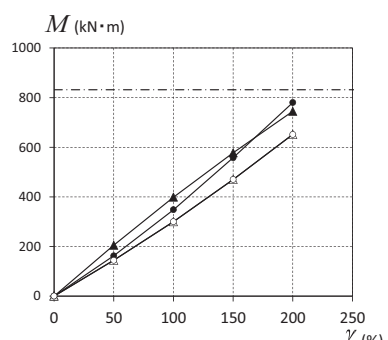

(f) $\sigma$ 20-Pin-N5
図 18 周辺部材の曲げモーメント(Pinの場合)

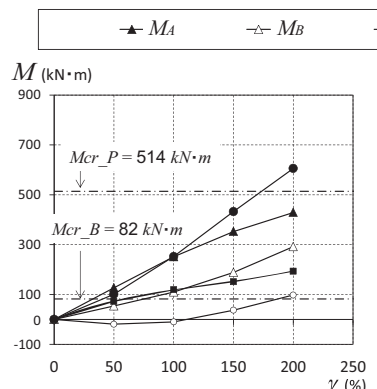

(a) $\sigma 10-300-\mathrm{N} 1$

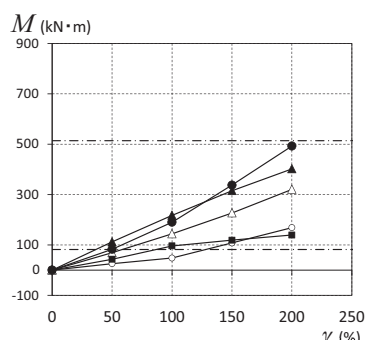

(c) $\sigma 10-300-\mathrm{N} 3$

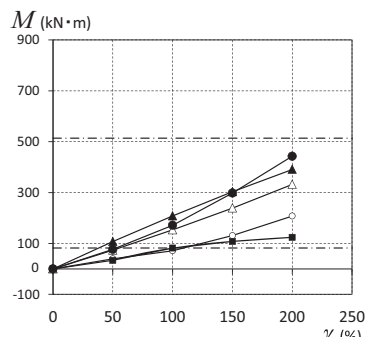

(e) $\sigma 10-300-\mathrm{N} 5$

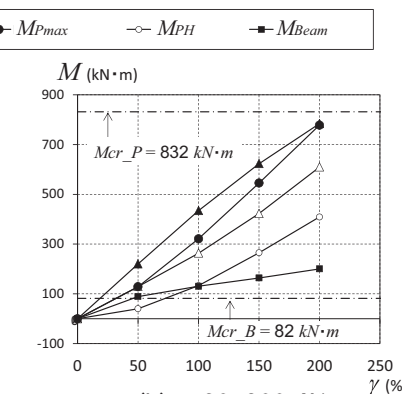

(b) $\sigma$ 20-300-N1

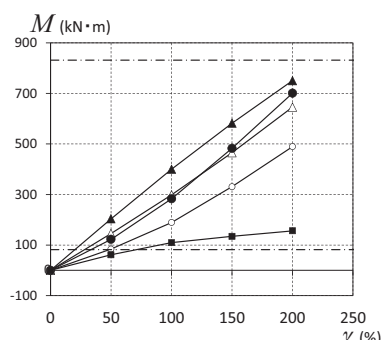

(d) $\sigma 20-300-\mathrm{N} 3$

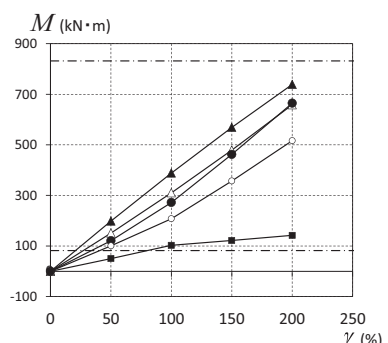

(f) $\sigma 20-300-\mathrm{N} 5$
図 19 周辺部材の曲げモーメント(300の場合) 
面圧 $10 \mathrm{~N} / \mathrm{mm}^{2}$ の寸べてのパターンで杭中間部においてひび割れが 生じており，杭頭に対して杭中間部の曲げモーメントは相対的に大 きい。

図 19 では, 杭頭に接合される基礎梁両端の負担するモーメント の和をMBeam とする。基礎梁のひび割れモーメント $M_{c r} B$ は $41 \mathrm{kN} \cdot \mathrm{m}$ と非常に小さい值であり, 図 19(a)〜(f)のす心゙てにおいて, せん断ひずみ $50 \%$ 100\%の間で基礎梁のひび割れが確認できる。 なお, 図 19 に示寸 M Beam は両端の基礎梁が負担する曲げモーメン トの和であるため, 梁のひび割れモーメント $M c_{c} B$ も 2 倍の值で示 している。基礎梁が取付くことにより, 杭頭の負担モーメントは低 減される。基礎梁により連成解析モデルの回転剛性比の値は小さく なるため, 杭中間部の曲げモーメントも減少し, 杭中間部でのひび 割れを防ぐことができる。せん断ひずみの増加に伴い，せん断ひず みレベルが小さいときは, 杭頭の曲げモーメントよりも基礎梁の負 担する曲げモーメントの方が大きいが，せん断ひずみレベルが大き くになるにつれて基礎梁の負担モーメント M Beam と杭頭の負担モ 一メント MPH の大小関係が入れ替わるケースが確認できる。これは, 基礎梁のひび割れによって基礎梁の回転剛性が低下し, 杭頭の負担 する曲げモーメントが増加したためである。

図 18 および図 19 において, 積層ゴム上端部の曲げモーメント $M_{A}$ および下端部の曲げモーメント $M_{B}$ の増加の仕方はせん断ひず みによって変化し, せん断ひずみの増加に伴い上下端の曲げモーメ ントの差が小さくなる傾向を示す。また, 連成解析モデルの回転剛 性比が大きい $N$ 值=1 のようなケースでは, 杭体地中部の最大曲げ モーメント $M_{P \max }$ と杭頭曲げモーメント $M_{P H}$ の差が大きいが, 回 転剛性比が小さい $N$ 值=5 のようなケースになるほど差は小さくな る。このことから, 杭体に生じる曲げモーメント分布が図 17 に示 すように変化している傾向も確認できる。

\section{5. まとめ}

本論では, 端部回転を有する積層ゴムの剛性評価手法より, 積層 ゴム端部に取付く部材の剛性を評価し, 積層ゴム水平剛性低下率と 取付け部に作用する曲げモーメントの増加率について定量的評価を 行った。また, 杭頭免震構造の架構を想定し, 積層ゴムに取付く部 材の応力状態を示した。結論を以下にまとめる。

1）積層ゴム端部に取付く架構の回転剛性を評価した連結部材連 成モデルにより, 水平剛性低下率および端部回転角を評価した。 杭頭免震では面圧 $10 \mathrm{~N} / \mathrm{mm}^{2}$ で回転剛性比が 1.60 以下, 面圧 $20 \mathrm{~N} / \mathrm{mm}^{2}$ で回転剛性比が 0.75 以下であれば端部回転角を 0.01rad 以下とすることができる。

2）連結部材連成モデルにより, 積層ゴム上端部の曲げモーメント 増加率を評価した。杭頭免震建物では, 積層ゴムに取付く部材 の設計を行う際は, 端部回転が生じない場合に対して, 10〜 $20 \%$ 端部曲げモーメントの増加を見込む必要がある。

3）杭頭免震建物を想定した積層ゴム一杭一基礎梁連成解析モデ ルを作成し, 連成解析モデルの回転剛性比を算出した。本論の 解析モデルにおける回転剛性比の範囲は 0.25〜2.60 となった。 また, 積層ゴムの端部回転角には基礎梁および周辺地盤の $N$ 值 による回転拘束効果が大きく影響する。

4）連成解析モデルにおける各部材の曲げモーメントを比較した。
せん断ひずみの増加に伴い, 各部材が負担する曲げモーメント の変化および基礎梁の有無による影響を検討した。回転剛性比 が大きいパターンでは杭体にひび割れが生じるケースが確認 できた。また, 本解析における断面の基礎梁ではおよそせん断 ひずみ 50\% 100\%の間でひび割れが生じる結果となった。

\section{参考文献}

1) 猿田正明, 岡田敬一, 中村豊, 長谷部雅伸：2011 年東北地方太平洋沖 地震における免震建物の応答, 日本建築学会大会学術講演梗概集, B-2, pp.629-630, 2011.8

2) 日本建築学会 : 免震構造設計指針, 第 2 版, 1993

3）浅野三男, 峯脇重雄 : 取付部の柔性を考慮した免震用積層ゴムの水平剛 性評価，日本建築学会技術報告集，No.8，pp.57-62，1999.6

4）飯塚真巨: 積層ゴムの剛性マトリクス (Haringx 理論に基づく定式化), 日本建築学会大会学術講演梗概集, B-2, pp.619-620, 1995.8

5）飯塚真巨, 高岡栄治：ばねと剛体要素から成る積層ゴム用離散型力学モ デル, 日本建築学会構造系論文集, No.607, pp.81-85, 2006.9

6) 三山剛史 : 積層ゴムの上下面に回転を与えた場合の力学性状に関する研 究, 日本建築学会構造系論文集, No.556, pp.43-50, 2002.6

7）下田卓, 小林正人：積層ゴムの端部回転が取付け部曲げモーメントに及 ぼす影響, 日本地震工学会・大会-2011 梗概集, pp.174-175, 2011.11

8) 藤田聡, 藤田隆史: 重量機器免震用積層ゴムの静的加力実験 - 第三報 剛 性についての理論的検討 -, 生産研究 38 巻, 第 4 号, pp.27-29, 1986.4

9）西村拓也, 渡辺宏一：3 次元免震装置における積層ゴムの回転剛性評価 と解析モデルの検証, 清水建設研究報告, 第 87 号, pp.19-25, 2009.1

10）下田卓, 小林正人：取付け部の回転及び $\mathrm{P}-8$ 効果を考慮した積層ゴムの 水平剛性評価, 第 13 回日本地震工学シンポジウム(2010), pp.464-471, 2010.11

11）日本建築学会関東支部：免震・制振構造の設計 学びやすい構造設計, p.207, 2007

12）日本免震構造協会 : MENSHIN, No.52, pp.19-22, 2006.5

13）日本免震構造協会：JSSI 免震構造施工標準 2009, pp.78-79, 2009

14）日本建築学会 : 鉄筋コンクリート構造計算規準・同解説 2010, 2010

15）日本建築学会 : 建物と地盤の動的相互作用を考慮した応答解析と耐震設 計, 2006 